\title{
Residential Air Conditioning System Integrated with Packed Bed Cool Storage Unit for Promoting Rooftop Solar PV Power Generation
}

\author{
Kesavan Muthaiyan ${ }^{1}$, Rajamani Narayanasamy², Chidambaram Lakshmanan¹, \\ Pandiyarajan Vellaichamy ${ }^{3}$, Velraj Ramalingam ${ }^{2 *}$ \\ ${ }^{1}$ Mechanical Engineering, Annamalai University, Annamalai Nagar - 608 002, India \\ ${ }_{2}^{2}$ Institute for Energy Studies, Anna University, Chennai - 600 025, India \\ ${ }^{3}$ Department of Chemical Engineering, Anna University, Chennai - 600 025, India
}

\begin{abstract}
The increase in the share of renewable-based power in the gross power generation in most countries causes significant concerns over the addition of renewable power with the grid, results in stability issues in most developed nations. Energy storage is an emerging technology that is considered the ultimate solution in developing microgrids with distributed renewable power generation. The cool thermal storage plays a vital role in economically promoting renewable power among different storage units. The major objective of the research work is to demonstrate the integration of residential air-conditioning systems with packed bed cool storage units to promote rooftop solar power generation for residential space cooling applications. In order to achieve the said objective, an experimental investigation was made to study the charging/discharging characteristics of a packed bed cool-storage unit combined with a chiller and a cooling coil unit suitable for small capacity air-conditioning applications. The system consists of encapsulated spherical capsules filled with a phase change material blended with distilled water and pseudomonas (nucleating agent) and the heat transfer fluid as a combination of distilled water and Mono-ethylene glycol. A cooling coil unit was connected to the cool-storage tank to transfer cool energy from the storage tank to the space to be cooled when there is a demand. The important parameters, such as instantaneous and cumulative heat transfer during the charging/discharging processes, are presented. The average COP values of the chiller during the charging operation were estimated as $1,0.93$, and 0.89 when the $\mathrm{HTF}$ setpoint temperatures were $-6^{\circ} \mathrm{C},-9^{\circ} \mathrm{C}$, and $-12^{\circ} \mathrm{C}$, which shows a decrease in performance as the setpoint temperature decreases. During the discharging process, a cooling load of $2.25 \mathrm{~kW}$ is obtained during the first cycle of operation and gradually reduces to $0.3 \mathrm{~kW}$ during the sixth cycle of operation. The increase in the HTF temperature during each cycle of operation indicates that the Phase Change Material (PCM) in the balls cannot release the heat as per the demand after a certain period of discharging. Hence, decreasing the internal thermal resistance by suitable measures is essential to achieve uniform heat flux and to operate the system successfully
\end{abstract}

Keywords: Cool thermal energy storage; Solar Air Conditioning, Demand-side management; Residential Building cooling; Phase change material

Article History: Received: 26 th Oct 2020; Revised: $7^{\text {th }}$ Dec 2020; Accepted: $15^{\text {th }}$ Dec 2020; Available online: $20^{\text {th }}$ Dec 2020

How to Cite This Article: Muthaiyan, K., Narayanasamy, R., Lakshmanan, C., Vellaichamy, P., Ramalingan, V. (2021), Residential Air Conditioning System Integrated with Packed Bed Cool Storage Unit for Promoting Rooftop Solar PV Power Generation. Int. Journal of Renewable Energy Development, 10(2), 239-247.

https://doi.org/10.14710/ijred.2021.33750

\section{Introduction}

The economic growth of a nation depends on the total capacity of power generation, energy utilization, and environmental preservation. The building sector takes approximately $40 \%$ of the energy generated in many of the developing and developed countries. In tropical countries, the most energy consumption in building sector is because of large capacity air-conditioning units that consume approximately 60 percentage of the energy spent on building. Hence, many countries like India, located near the equator, spend nearly $24 \%(60 \%$ of $40 \%)$ of the total power generated for air-conditioning. The integration of cool thermal storage units (CTES) is one of the best ways in the central air-conditioning system to match the load variations between peak and off-peak hours and reduce the installation capacity needed for the chiller system.

Among the different types of cool thermal storage units, the phase change material encapsulated in spherical capsules in packed bed storage unit is best suited for air-conditioning applications owing to its high storage density and small temperature variations during the cyclic processes of energy storage and release. This kind of storage unit consumes nearly $10-15 \%$ more power than conventional air-conditioning system as the cool energy generated is at a temperature lower than that of the conventional system. However, in recent years, the promotion of solar and other renewable energy helps the efficient use of renewable energy for building applications,

\footnotetext{
* Corresponding author: velrajr@gmail.com
} 
causing an appreciable decrease in the air-conditioning unit's operating cost. Hence, this kind of cool-storage unit for building air-conditioning has drawn scientists' attention in the emerging green building scenario.

Water-ice phase change is being considered as the potential PCM in building air-conditioning applications owing to its advantageous thermal properties and bounteous availability. Chen and Yue (1991) have studied the thermal performance of a packed bed storage system with spherical capsule filled with water as PCM for air conditioning applications and shown that more than $75 \%$ of the cool energy was stored as latent heat and the rest was stored as sensible heat. Velraj, Cheralathan and Renganarayanan (2006) made an extensive investigation of the CTES unit, integrated with a large building airconditioning unit. They have listed the system's advantages and reported integrating the CTES unit resulting in a saving of Rs 2260 thousands per annum for the considered building. Cheralathan, Velraj and Renganarayanan (2007) carried out a study on the performance of an industrial refrigeration unit, with an encapsulated PCM based CTES unit. Their results revealed a decrease in evaporator temperature by $1^{\circ} \mathrm{C}$ resulting a $3-4 \%$ increase in specific energy consumption (SEC) and $1^{\circ} \mathrm{C}$ fall in the condensing temperature leading to a $2.25-3.25 \%$ fall in SEC. Bedecarrats et al. (2009) presented an experimental investigation to study the performance of encapsulated spherical capsules containing water with a nucleation agent as PCM and a mixture of mono ethylene and water as HTF, during the charging and discharging processes. Boonnasa and Namprakai (2010) reported an approach to find the optimised cool water energy storage (CWES) capacity and operational strategies for the $\mathrm{AC}$ loads at various electricity tariffs. They concluded that the continuous operation of the CWES system comprising two chiller units of cooling capacity $450 \mathrm{TR}$ each, a cool-storage of 9413 Ton-hr, and a volume of $5175 \mathrm{~m}^{3}$ was found to be suitable. Rismanchi et al (2012) attempted to predict the potential cost savings of employing ice thermal storage (ITS) systems in the office building cooling applications. They conducted experiments for three different scenarios of retrofitting $10 \%, 25 \%$ and $50 \%$ of the existing conventional AC systems with new ITS systems. They showed the result of the full storage strategy causing a reduction in the annual costs of the air conditioning system up-to 35 percent but this reduction was limited to around 8 percent for load leveling strategy. Rosiek and Garrido (2012) studied the performance of a solar-thermal operated vapour absorption chiller unit with chilled water storage tanks for building cooling application. It was seen that the efficacy of the solar-assisted cooling system got enhanced owing to the reduction in chiller on/off cycles due to the incorporation of chilled water storage tanks.

Rivarolo et al (2013) investigated the impact of uncontrollable generation of power from solar and wind integrated with $100 \mathrm{kWe}$ micro gas turbine, $20 \mathrm{kWe}$ internal combustin engine to produce electrical as well as thermal energy and $100 \mathrm{~kW}$ adsorption chiller to produce cool energy. They showed the results that the interaction among the fossil and renewable resources and the importance of integrating suitable storage system in the Zhai et al. (2013) reviewed the phase change cool-storage for air-conditioning units focusing on phase change materials (PCMs) and applications. They have discussed the problems concerning heat transfer enhancement, phase change properties of composite PCMs, compatibility, etc. and suggested the need for further investigation. Sanaye and Shirazi (2013) modeled and optimised the ice thermal energy storage (ITES) unit for air conditioning applications. They showed a decrease in the annual electricity consumption and the carbon dioxide emission of the ITES unit by $9 \%$ and $9.8 \%$, respectively, compared to the conventional cooling system. Lin et al. (2013) provided a different air-conditioning unit with chilled water storage. Their results showed the possibility of saving the power consumption by $15-20 \%$ between the chilled water storage unit and the air-conditioning unit. Lin, Li and Cheng (2014) did a case study to assess saving potential in operational cost in a large air-conditioning system with some modification in the operational procedure. They demonstrated the ability of both the modified operational procedure to conserve energy and the cost of power than the system with chilled storage in the conventional mode. They were able to see the ability of the chilled water storage technology to save more than $5 \%$ of energy for the air-conditioning unit than the system used only for the difference between the peak and valley power tariff.

Mosaffa, Gaousi and Infante (2014) carried out an exergy analysis of an air-conditioning unit comprising latent heat thermal storage (LHTS) and vapour compression refrigeration (VCR) system. They concluded that there is an increase in exergy destruction due to an increase in operating potential difference. Sanaye and Hekmatian (2016) have done modeling and analyzed on an air conditioner with an ITES unit considering the energy, exergy, economic and environmental (4E) aspects in both partial and full load operating modes. They showed the ITES unit results in partial and full operating modes, resulting a decrease in the electricity utilisation $(11.83 \%$ for FOM and $10.23 \%$ for POM) compared to traditional unit. Rahdar, Emamzadeh and Ataei (2016) did a relative study on PCM (RT3HC) and ITES tank used in the airconditioning unit in office buildings. The results of their investigation showed the total energy utilisation of ITES and PCM units as $4.59 \%$ and $7.58 \%$ lesser than the traditional system, respectively. Falco, Capocelli and Giannattasio (2016) have done the performance study of a novel PCM-based unit for cool storage in civil airconditioning. They tested a $5 \mathrm{kWh}$ prototype of a storage tank to demonstrate the technological evaluation and performed simulation analysis using a numerical model. They showed the optimised heat exchanger configuration leading a minimal loading time of 54 min for the $5 \mathrm{kWh}$ storage tank when the charging capacity was $5.7 \mathrm{~kW}$.

Falco, Capocelli and Losito (2017) analyzed the airconditioning unit combining the Cold Peak unit in comparison with a traditional unit from the environment aspects using an LCA (Life Cycle Assessment) methodology. They have presented the LCA study report of the cold storage unit allowing an appreciable decrease in environmental foot-print with reference to Global Warming Potential, Acidification Potential, Eutrophication Potential, Eco-toxicity, Human Health and Fossil Depletion. Patil et al (2017) compared the technical and economic performance of a solar organic Rankine cycle (s-ORC) system with thermal energy 
storage (TES) and a solar photovoltaic (PV) system with battery storage at a capacity of $50 \mathrm{kWe}$. They indicated the optimum operational zones of five performance, namely annual energy generation, capacity utilization factor (CUF), capital cost, levelized cost of electricity (LCOE) and energy wasted. They showed the results that the minimum LCOE estimated for the s-ORC system was 0.19 USD/kWh with a capacity utilization factor-CUF of 0.56 and for the same CUF value, the PV system incurs a LCOE of at least $0.26 \mathrm{USD} / \mathrm{kWh}$. The minimum LCOE of the PV system yields an attractive value of $0.12 \mathrm{USD} / \mathrm{kWh}$, but it includes no battery storage and thus delivers a significantly lower CUF of 0.27 . The results indicate that for achieving minimum LCOE, the operational zones of the two technologies differ in terms of storage requirement. Arcuri et al (2017) analysed the techno economic aspects in the use of PCM based cool thermal storage system in five commercial buildings at five different cities in Brazil using two different operation strategies and two types of chillers for new installations and retrofits. Their objective was to fill the gap of evidence by assessing the benefits of CTES technology for a wider scale integration in Brazil's commercial sectors. Two cases of operations were considered and comparison was made. In the first case, the CTES system was designed only for the purpose of eliminating the chiller operation during onpeak time, supplying full storage from 17:00 to 20:00 hours. In the second case, the CTES system was designed for eliminating chiller operation during on-peak time and reducing demand charges through supply of full storage from 17:00 to 20:00 hours and a partial storage from 08:00 to 17:00 hours and 20:00 to 22:00 hours. The charging time was from 20:00 to 08:00 hours for both strategies.

Luo et al (2017) studied the data-driven analytics and modeling to holistically understand the operation of an ice-based TES system in a shopping mall, calculating the system's performance using actual measured data from installed meters and sensors. They showed the results that there is significant savings potential when the current operating strategy is improved by appropriately scheduling the operation of each piece of equipment of the TES system, as well as by determining the amount of charging and discharging for each day. They developed a novel optimal control strategy to minimize the TES system's operating costs determined by an optimization algorithm of Sequential Quadratic Programming.

Zhu et al (2018) evaluated the techno-economic feasibility of integrating the cold energy storage system and the electrical energy storage system in a refrigerated warehouse for shifting the power consumption. They developed a dynamic model in TRNSYS and showed the results that, the integration of cold energy storage can reduce the electricity consumption and operational cost by $4.3 \%$ and $20.5 \%$, respectively.

Aljehani et al. (2018) designed and optimized a hybrid air-conditioning unit with thermal energy storage unit using phase change composite material comprising of paraffin wax and expanded graphite as a feasible storage medium. They have proposed and tested a hypothesis with Aspen Plus software that integrates a conventional AC unit with a PCC-TES, that would result in considerable profits concerning size and efficiency of the compressor, electricity utilised, and carbon dioxide emissions. Further contribute to a reduction in the demand for electricity during hours of high demand and reducing the need to build more costly power plants and transmission lines. Song et al. (2018) studied the economic viability of ice storage implementation and chilled water storage combined LTSHS system for building cooling applications. They concluded that an ice thermal storage unit's addition to an existing CWES system significantly reduced the design day operating cost. Pina et al (2018) analysed the thermo economic concept of trigeneration system. They showed results that the trigeneration system is more profitable than the reference system, with total cost savings of $9,942 € / y r$, which was translated into the lower annual total unit costs of the final products.

Wang et al (2019) investigated the randomness of residential PV generation and the random load demand, which may affect the efficiency and reliability of the power grid. They formulated a stochastic programming problem to provide a pricing strategy to customers for the optimal demand response in smart grid. Further reported the performance of the proposed stochastic demand response scheme evaluated through extensive simulations indicates that this novel scheme can help both power system operators and electrical customers to better decide on their operating schedule and energy usage respectively.

It is construed from the above literature that there are various benefits such as chiller downsizing, operational cost reduction, environmental benefits, etc. through integrating the cool thermal storage unit with airconditioning applications. However, these kinds of storage units are studied only for large scale building airconditioning applications. The integration of a packed bed cool thermal storage unit for residential air-conditioning applications has not been reported. In recent years, there is an extensive promotion of rooftop solar PV system in the residential sectors. The air-conditioning requirement in the residential sectors will be in the evening and night hours. Hence, to match the air-conditioning demand with solar energy availability, the cool-storage unit to be integrated with the air-conditioners. Considering the above, this research focuses on developing a pilot-scale cool-storage unit packed with spherical balls filled with water as PCM to investigate the charging/discharging characteristics of the said system for residential applications. This investigation will help deploy solar energy for residential air-conditioning applications in the near future.

\section{Material and Methods}

\subsection{Experimental investigation}

In the present work, an experimental set up was constructed for charging the cool energy produced by a chiller in the PCM based storage tank. A suitable cooling coil unit was designed, procured, and placed in the room to be cooled, and the heat transfer fluid in the storage tank was circulated through a cooling coil unit for space cooling. An experimental investigation was done to investigate the system's charging/discharging behavior to analyze such a system's feasibility for residential applications. The experimental setup details and the charging/discharging experiments performed were explained. 


\subsection{Experimental setup}

The schematic representation of the experimental arrangement, which consists of a VCR system, CTES tank, a cabin, and a cooling coil unit as the major components. is shown in Fig 1. In this investigation, the vapour compression refrigeration (VCR) system of 1-ton capacity produced chilled brine at the required temperature range of $-6^{\circ} \mathrm{C}$ to $-12^{\circ} \mathrm{C}$. A CTES tank, made of stainless steel material, with a capacity of $0.212 \mathrm{~m}^{3}$ was connected to the evaporator of the VCR system, and the chilled brine produced in the chiller was circulated through this storage tank during the charging process as shown in figure.1.The storage tank was packed with high-density polyethylene (HDPE) spherical balls of $75 \mathrm{~mm}$ dia. The balls were filled with PCM to its $95 \%$ volume $(150.2 \mathrm{ml})$. PCM was a mixture of distilled water with $0.13 \%$ of pseudomonas

The mass of PCM retained in the 600 PCM balls was $90.12 \mathrm{~kg}$. The tank was occupied with distilled water (60\%) and mono-ethylene glycol (40\%) mixture as brine in the CTES system that surrounds the PCM capsules and performing as the HTF. The VCR system had a buffer tank of capacity $0.009 \mathrm{~m}^{3}$ wherein the evaporator coil was immersed and installed with a heating coil of $2000 \mathrm{~W}$ capacity. A proportionate differential temperature controller was used for maintaining a desired constant temperature in the buffer tank. This enabled a constant temperature HTF from the buffer tank to the cool thermal storage tank. Valves were provided for controlling the flow rate of $\mathrm{HTF}$ in the charging/discharging circuits. The cooling coil unit was kept in a cabin of size $2 \mathrm{~m} \times 2.7 \mathrm{~m} \times 2.72$ $\mathrm{m}$. During the discharging processes the cool HTF from the CTES tank was circulated through the cooling unit and returned to the CTES tank. Thus as shown in the figure. 1 the cabin was kept at a controlled temperature of $26^{\circ} \mathrm{C}$ to $28^{\circ} \mathrm{C}$ during the discharging experiment.

The temperatures at various PCM locations in the balls were measured using PT 100 - RTD, with $\pm 0.1^{\circ} \mathrm{C}$ accuracy. T-type thermocouples were connected to measure the HTF temperatures at all entry and exit locations and at various heights in the storage tank.
Further, 3 RTDs were kept at various locations in the cabin to measure the room air temperature during the discharging process. All the temperature sensors were linked to a data acquisition unit of Agilent make 34972A that had $0.004 \%$ accuracy. The HTF flow rate from the chiller to the CTES tank and from the CTES tank to the indoor unit of the air-conditioning was measured using rotameters with the measuring range of 0-1000 LPH.

\subsection{Experiments}

Two sets of experiments were done to investigate the charging and discharging characteristics of the developed system. During the charging experiment, HTF was circulated from the evaporator bath in the chiller unit to the CTES tank using a pump, and the required mass flow rate of HTF in the system was circulated by adjusting the valves. The chiller unit was operated at a constant load. PDTC was used to maintain the HTF's desired bath temperature in the evaporator tank and for changing the heating coil output on the basis of temperature sensors located in the HTF bath of the evaporator tank.

The HTF and the PCM temperatures at specified locations were scanned using a data logger and stored in the desktop PC connected to the experimental setup. Experiments were carried out by varying the bath temperature in the evaporator tank and a mass flow rate of $360 \mathrm{LPH}$. Initially, the temperature of the HTF bath was kept at $-6^{\circ} \mathrm{C}$ using the PDTC controller. The VCR system was continuously operated and, after a particular duration, the complete PCM in the balls reached crystallization, and continued the experiments until the $\mathrm{PCM}$ temperature reached $-2 \pm 0.5^{\circ} \mathrm{C}$. The $\mathrm{HTF}$ and $\mathrm{PCM}$ temperature were recorded once in 10 seconds using a data acquisition unit till the end of the experiment, while energy meter readings were noted once in every half an hour. Repeated experiments were performed by maintaining the bath set-point temperature of $-9^{\circ} \mathrm{C}$ and $12^{\circ} \mathrm{C}$ keeping the same $360 \mathrm{LPH}$ mass flow rate. The uncertainties of the measured and evaluated data were estimated, and the values are shown in Table 1.

Table 1

Uncertainty in measured and estimated quantities

\begin{tabular}{|ccc|}
\hline Parameters & $\begin{array}{c}\text { Measured values/Range of } \\
\text { experiment values }\end{array}$ & Uncertainty \\
\hline Diameter of spherical capsule & $75 \mathrm{~mm}$ & $\pm 0.02 \mathrm{~mm}$ \\
Temperature & -6 to $32{ }^{\circ} \mathrm{C}$ & $\pm 0.15{ }^{\circ} \mathrm{C}$ \\
Volume & $100 \mathrm{ml}$ & $\pm 0.015 \mathrm{ml}$ \\
Mass flow rate & 360 to $400 \mathrm{lph}$ & $\pm 2.7 \%$ \\
& Derived quantities & $\pm 1.85 \%$ \\
\hline Instantaneous heat transfer & $0.65 \mathrm{~kW}$ & \\
\hline
\end{tabular}




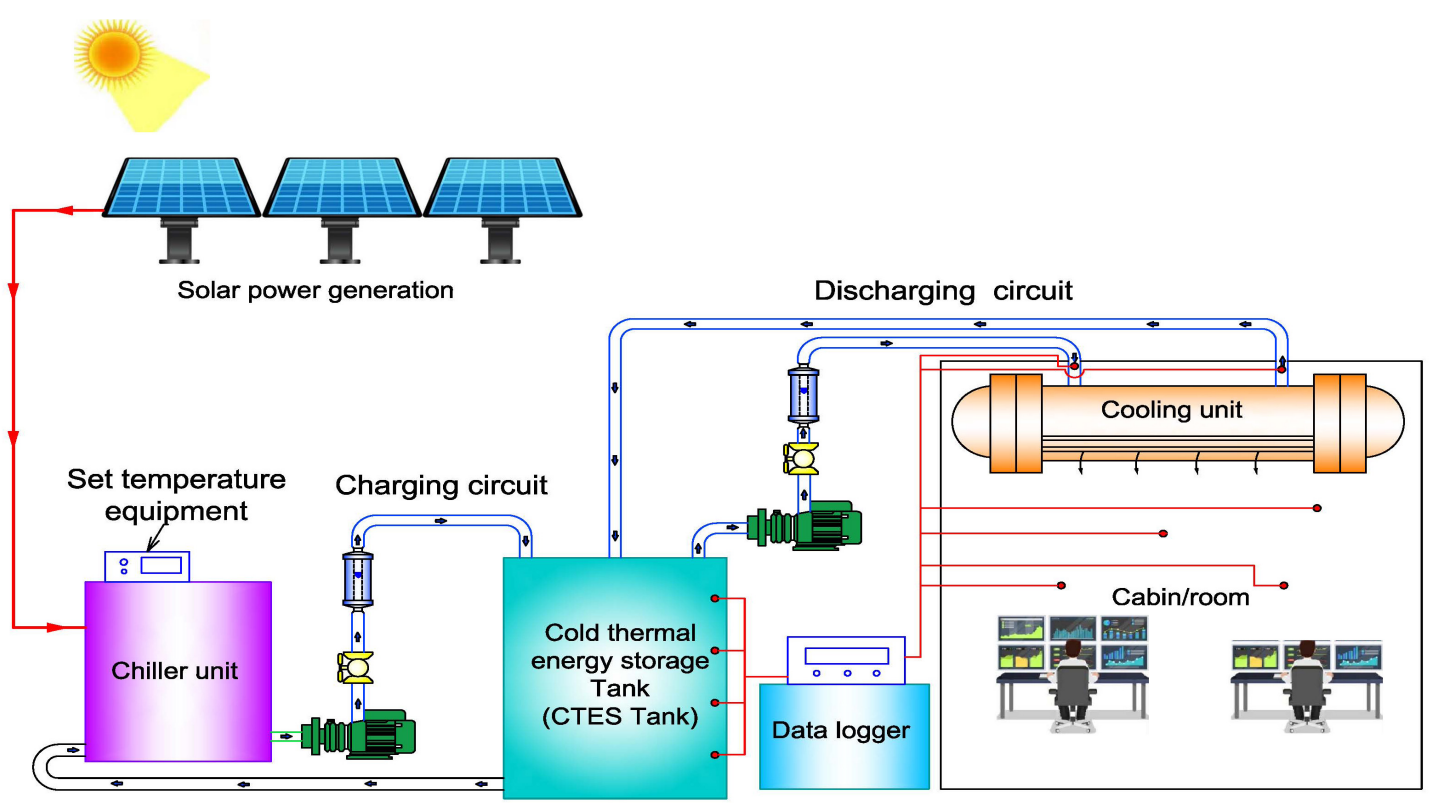

Fig.1 Schematic diagram of the experimental setup

Discharging experiments were carried out by circulating the HTF to flow between the CTES tank and the cooling coil unit, kept in the room to be cooled using a pump. The mass flow rate of the HTF was maintained uniformly at 2.5 LPM using the valve arrangement while the flow rate was measured using a flow meter. The room temperature was measured in three different locations, one in front of the cooling coil unit and the other two at suitable locations in the room for arriving at the average temperature of the room. The HTF at the inlet and outlet locations of the cooling coil unit kept in the room were also measured continuously during the experiment. The chilled water flow from the storage tank to the cooling coil unit was appropriately controlled for maintaining the room temperature within $27 \pm 1^{\circ} \mathrm{C}$. The discharging experiments were discontinued when the available chilled water from the storage tank could not attain the room temperature of nearly $26^{\circ} \mathrm{C}$. Several experiments were conducted to ensure their repeatability.

\section{Results and Discussion}

The results of the experiments conducted during the charging of the storage tank and the cooling of the cabin by discharging the cool thermal storage tank are shown and discussed in this section.

\subsection{PCM Temperature-variation in the storage tank}

Figure 2 shows the average temperature of the PCM in the storage tank with respect to time for various inlet HTF temperatures of $-6^{\circ} \mathrm{C},-9^{\circ} \mathrm{C}$, and $-12^{\circ} \mathrm{C}$ with $360 \mathrm{LPH}$ mass flow rate. It is observed that the PCM temperature varies almost linearly from $32^{\circ} \mathrm{C}$ till the start of solidification, and it took nearly $450 \mathrm{~min}$ for all inlet HTF temperatures. During the start of solidification, in the case of $-9^{\circ} \mathrm{C}$ and $12^{\circ} \mathrm{C}$, a small level of sub-cooling was observed to the extent of $1^{\circ} \mathrm{C}$ and $0.5^{\circ} \mathrm{C}$, respectively, whereas, in the case of $-6^{\circ} \mathrm{C}$, the subcooling was eliminated. Kumaresan et al. (2013) had reported that the subcooling was to an extend of $3.8^{\circ} \mathrm{C}$ without pseudomonas when the surrounding HTF was maintained at $-9^{\circ} \mathrm{C}$. Chandrasekaran, Cheralathan and Kumaresan (2014) have also reported the total elimination of the subcooling with pseudomonas and nanoparticle in the PCM. In the above-referred articles, experiments were conducted for a single spherical capsule filled with PCM either without pseudomonas or with pseudomonas plus nanoparticles. However, in this investigation, the subcooling was eliminated almost completely with the addition of only pseudomonas in the PCM, and the experiments were conducted with a coolstorage tank packed with PCM balls. During the phase change process, there was a noticeable variation in the time required for a complete phase change. The phase change process duration was $250 \mathrm{~min}, 210 \mathrm{~min}$, and 190 min for the inlet HTF setpoint temperature of $-6^{\circ} \mathrm{C},-9^{\circ} \mathrm{C}$, and $-12{ }^{\circ} \mathrm{C}$ respectively.

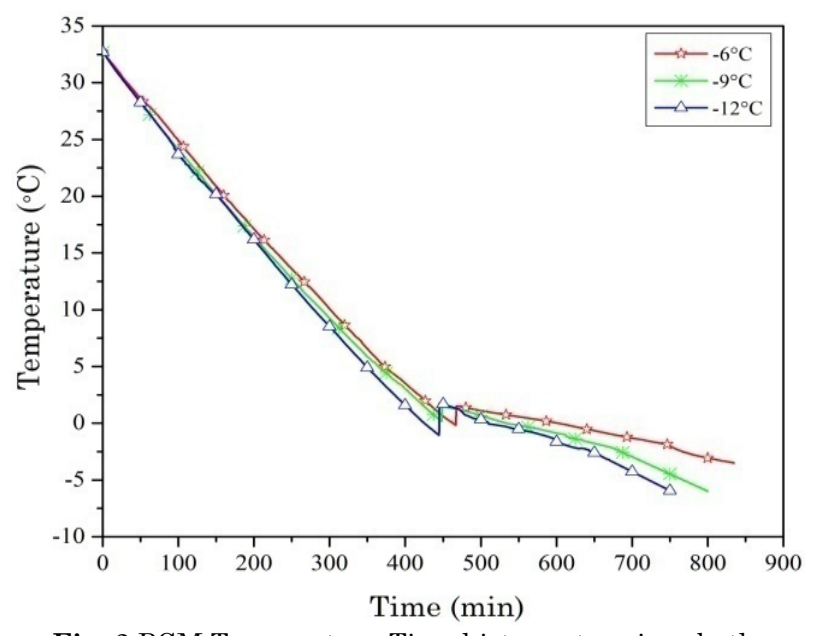

Fig. 2 PCM Temperature-Time history at various bath temperatures for $360 \mathrm{LPH}$ mass flow rate 
Citation: Muthaiyan, K, Narayanasamy, R., Lakshmanan, C., Vellaichamy, P., Ramalingan, V. (2021), Residential Air Conditioning System Integrated with Packed Bed Cool Storage Unit for Promoting Rooftop Solar PV Power Generation, Int. Journal of Renewable Energy Development, 10(2),239-247, doi: 10.14710/ijred.2021.33750

Page 1244

\subsection{Instantaneous and Cumulative heat transfer}

Figure 3 shows the instantaneous heat transfer in the storage tank, which was evaluated from the measured temperature difference of the HTF between the inlet and outlet of the storage tank continuously with respect to time. The figure shows the presence of a slow and steady decrease in the instantaneous heat transfer from the initial approximate value of $1.5 \mathrm{~kW}$ for all the setpoint temperature of $-6^{\circ} \mathrm{C},-9^{\circ} \mathrm{C}$ and $-12^{\circ} \mathrm{C}$ in the chiller bath. In the case of $-12^{\circ} \mathrm{C}$ after $280 \mathrm{~min}$, there was a sudden decrease in heat transfer until $400 \mathrm{~min}$. This sudden decrease was observed from $400 \mathrm{~min}$ to $550 \mathrm{~min}$ in the case of $-6^{\circ} \mathrm{C}$ and $-9^{\circ} \mathrm{C}$. This phase of a sudden decrease in heat transfer before the start of solidification was due to the very low-temperature difference between the HTF in the storage tank and PCM in the spherical balls. However, after the start of solidification, the sudden decrease in heat transfer was stopped, and a near-constant instantaneous heat transfer was observed for a longer duration. During this phase change process, an average instantaneous heat transfer of $0.65 \mathrm{~kW}, 0.55 \mathrm{~kW}$, and 0.45 $\mathrm{kW}$ were observed for the HTF setpoint temperatures of $12^{\circ} \mathrm{C},-9^{\circ} \mathrm{C}$, and $-6^{\circ} \mathrm{C}$ respectively. This part of the instantaneous heat transfer was highly essential for the design of the storage tank as the PCM in the storage tank would not be allowed to cause a decrease in its temperature below $+5^{\circ} \mathrm{C}$ during the repeated charging and discharging process. The maintenance of a lower setpoint temperature in the chiller was operationally expensive. However, there was an increase in instantaneous heat transfer when the setpoint temperature was brought to a lower level. Hence, the requirement was to select a suitable setpoint temperature for the chiller based on the instantaneous heat transfer and operation cost at various setpoint temperature.

Figure 4 shows the cumulative energy stored in the storage tank with respect to time for all bath set point temperatures when the mass flow rate was kept at 360 $\mathrm{LPH}$. The figure shows a linear increase in the cumulative heat transfer at the same rate for all bath setpoint temperatures during sensible cooling.

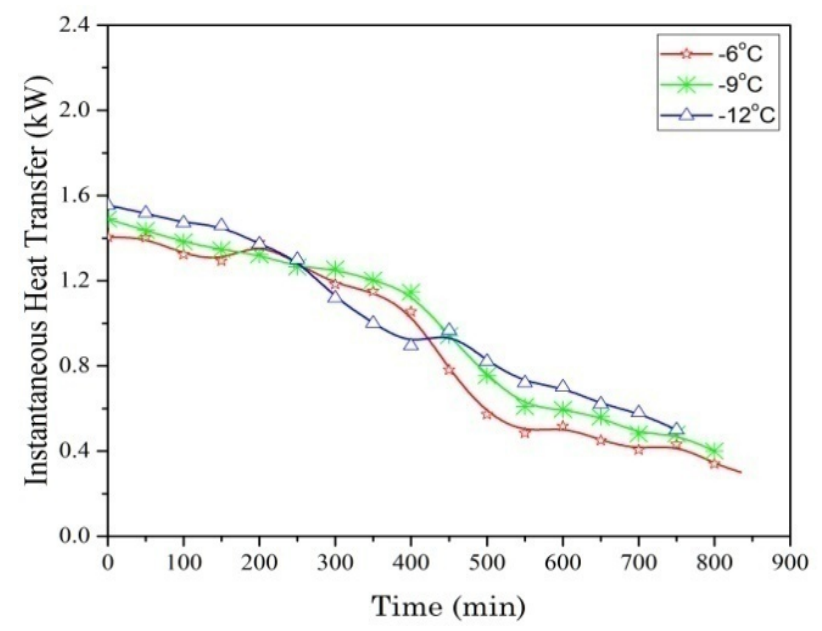

Fig 3. Instantaneous heat transfer in the storage tank for various bath temperatures at a mass flow rate of $360 \mathrm{LPH}$

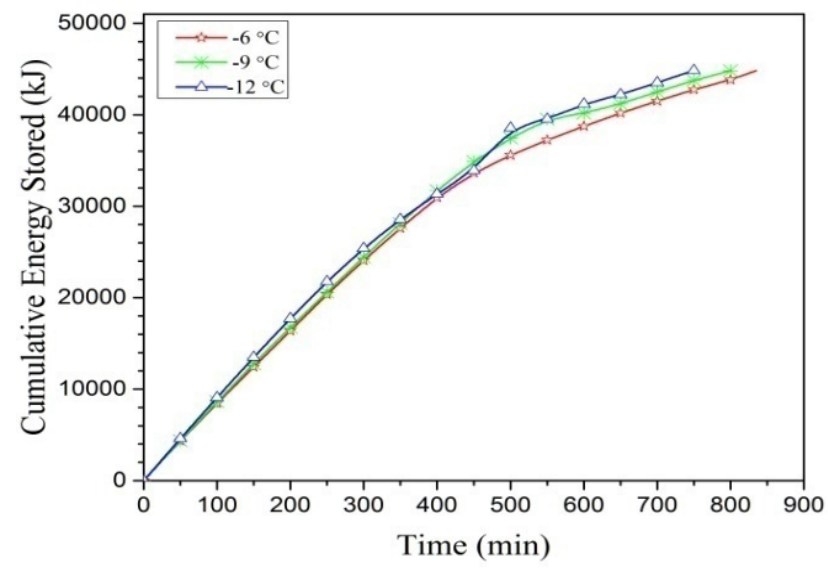

Fig.4 Cumulative energy stored for different bath temperatures with $360 \mathrm{LPH}$ mass flow rate

During the phase change process, there was a decrease in the slope with respect to time due to the solidified layer's increasing resistance. During the complete charging, approximately $45,000 \mathrm{~kJ}$ was stored in the storage tank at all bath setpoint temperatures of $-6^{\circ} \mathrm{C}$, $-9^{\circ} \mathrm{C}$, and $-12^{\circ} \mathrm{C}$ though this was achieved with a smalltime difference. The time taken for the entire charging was $760 \mathrm{~min}, 800 \mathrm{~min}$, and $840 \mathrm{~min}$, respectively, for the bath setpoint temperatures of $-6^{\circ} \mathrm{C},-9^{\circ} \mathrm{C}$, and $-12^{\circ} \mathrm{C}$. During the chiller's operation, the energy meter showed 1 $\mathrm{kW}$-hr for every one-hour operation for all the setpoint temperature. The reduction in the setpoint temperature caused a reduction in the COP of the chiller. The average values of the COP of the chiller during the charging operation was estimated as $1,0.93$ and 0.89 when the HTF setpoint temperatures were $-6^{\circ} \mathrm{C},-9^{\circ} \mathrm{C}$ and $-12^{\circ} \mathrm{C}$, respectively.

\subsection{Discharging process (supply of stored cool energy for air-conditioning)}

The temperature-time history of the HTF at the entry and exit of the indoor cooling unit and room when the setpoint temperature in the room was kept between $26^{\circ} \mathrm{C}$ and $28^{\circ} \mathrm{C}$,are presented in figure 5 . and the cooling load variation is presented in figure 6 . when the mass flow rate of the HTF was kept at 3 LPM. These results are discussed under two subsections

\subsubsection{Effect of inlet temperature variation}

It is observed from the figure 5 that the inlet temperature to the cooling unit continuously increase as the cool energy stored in the CTES tank reduces with respect to time. The average temperature difference between the outlet and inlet of the cooling unit during the first cycle of operation is approximately $11^{\circ} \mathrm{C}$ and this temperature difference decreases gradually during the successive cycle of operation. This is due to decrease in the average temperature potential between the room and cooling unit. During each cyclic operation, once the circulation is on, the cooling unit's outlet temperature increases suddenly for a short duration after the room temperature reached $28^{\circ} \mathrm{C}$. This was due to the heat accumulated during the cooling unit's idle condition between each cycle that delivered the heat to the circulating fluid. 


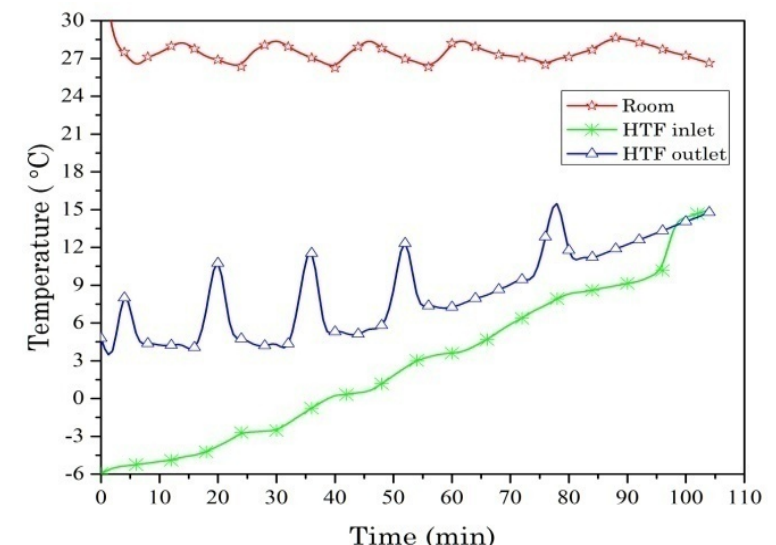

Fig. 5 Temperature-Time history of the cabin and the HTF inlet/outlet of the cooling coil unit.

It is also observed that there is an increase in the time span for successive cycles (time taken from $26^{\circ} \mathrm{C}$ to $28^{\circ} \mathrm{C}$ and back to $26^{\circ} \mathrm{C}$ in one cycle) as the entry HTF temperature in the cooling unit increases. When the entry $\mathrm{HTF}$ temperature reached $14^{\circ} \mathrm{C}$, bringing down the room temperature to $26^{\circ} \mathrm{C}$ was not possible, and hence the experiment was stopped at that stage. It was observed that the room could be maintained at the required comfort condition for $105 \mathrm{~min}$. The inlet temperature of the HTF in the cooling unit represented the HTF temperature in the storage tank. Hence, it is construed that the PCM balls cannot discharge energy from the balls as time increases due to increasing resistance offered by the melted PCM near the heat transfer surface for further melting the PCM in the interior region.

\subsubsection{Cooling load variation.}

The instantaneous heat removed from the cabin by the HTF during the discharging operation was evaluated using the inlet and outlet HTF temperature passing through the cooling unit. This is presented in figure 6 . The figure shows that the cooling load as $2.25 \mathrm{~kW}$ during the first cycle of operation and gradually reduces to $0.3 \mathrm{~kW}$ during the sixth cycle of operation. The duration for each cycle of operation, shown in the x-axis, increased in the successive cycles. An evaluation showed that the cooling load requirement for the cabin considered in the present experiment is approximately $0.55 \mathrm{~kW}$ for a setpoint temperature of $26^{\circ} \mathrm{C}$. The figure shows that the time required to bring the setpoint temperature of $26^{\circ} \mathrm{C}$ from $28^{\circ} \mathrm{C}$ is low, when the capacity of the cooling unit was high during the initial cycle, and it increases during each cycle. During the fifth cycle, when the cooling capacity was approximately $0.8 \mathrm{~kW}$, the setpoint temperature was brought back within 12 min. During this cycle, the inlet HTF temperature to the cooling unit was around $8^{\circ} \mathrm{C}$. During the sixth cycle, when the cooling coil unit delivered a cooling load of $0.3 \mathrm{~kW}$, it was not possible to bring the room temperature back to $26^{\circ} \mathrm{C}$, as the cooling load required for the cabin was more than $0.3 \mathrm{~kW}$. Hence a continuous supply of water at a minimum temperature of $8^{\circ} \mathrm{C}$ to $9^{\circ} \mathrm{C}$ was required to maintain the sustained cooling inside the cabin.

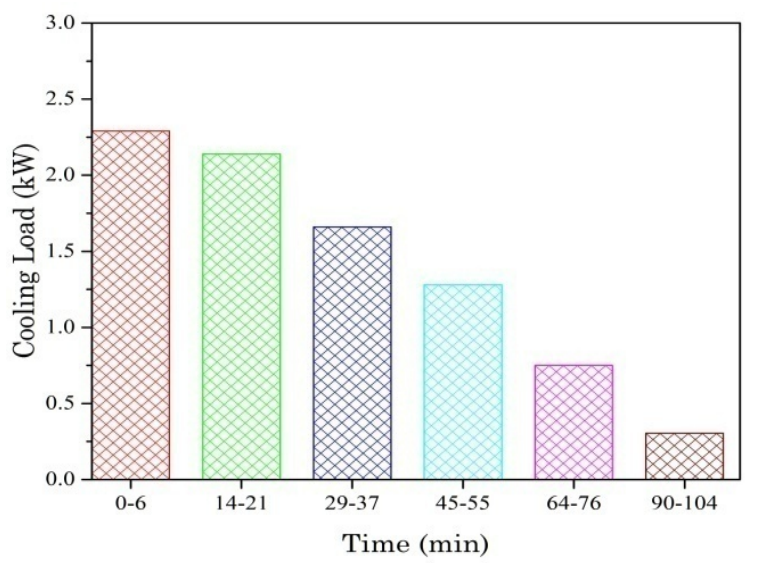

Fig. 6 Cooling load during each cycle of operation

It is construed from the above results that the PCM balls must be capable of releasing the required cool energy continuously based on demand during the discharging process. Hence when the cooling demand is higher than the heat transfer rate possible from the PCM balls, the heat transfer fluid temperature increases during each cycle of operation, and after a particular duration, the heat transfer fluid is not capable of providing the required heat transfer to achieve the set temperature inside the cabin. Hence, a careful design is required to match the heat transfer capability between the PCM balls and the HTF based on the demand during the discharging operation. Further, as the initial heat transfer is higher, enhancing the surface convective heat transfer coefficient will not be helpful; the actual requirement is to reduce the conductive resistance inside the PCM region. Hence, introducing suitable measures such as dispersion of nanoparticles in the PCM, adopting different geometrical arrangements for the PCM container will be a better solution to reduce the increasing conductive resistance inside the PCM, which will vary with respect to time as the distance between the unsolidified PCM interface layer and the heat transfer surface increases.

\section{Conclusion}

The major conclusions arrived at from the charging/discharging experiments made in the present work are summarized. During the charging process, the storage tank's temperature varies linearly from $32^{\circ} \mathrm{C}$ till the start of solidification, and it took nearly $450 \mathrm{~min}$ for all inlet HTF temperatures. During the phase change process, a near-constant temperature was maintained, and the duration was $250 \mathrm{~min}, 210 \mathrm{~min}$, and $190 \mathrm{~min}$ for the inlet HTF setpoint temperatures of $-6^{\circ} \mathrm{C},-9^{\circ} \mathrm{C}$ and $12^{\circ} \mathrm{C}$, respectively. Further, there was an increase in the instantaneous heat transfer when the setpoint temperature was brought to a lower level. The average COP values of the chiller during the charging operation were estimated as $1,0.93$, and 0.89 when the HTF setpoint temperatures were $-6^{\circ} \mathrm{C},-9^{\circ} \mathrm{C}$, and $-12^{\circ} \mathrm{C}$, which shows a decrease in performance as the setpoint temperature decreases. Maintenance of lower setpoint temperatures in the chiller was operationally expensive. Hence, it is 
Citation: Muthaiyan, K, Narayanasamy, R., Lakshmanan, C., Vellaichamy, P., Ramalingan, V. (2021), Residential Air Conditioning System Integrated with Packed Bed Cool Storage Unit for Promoting Rooftop Solar PV Power Generation, Int. Journal of Renewable Energy Development, 10(2),239-247, doi: 10.14710/ijred.2021.33750

Page 1246

essential to increase the PCM's heat transfer capabilities to the HTF with a minimum temperature difference. The discharging process showed that the heat transfer fluid is not capable of providing the required heat transfer to achieve the set temperature inside the cabin after a few cycles of operation. Hence, decreasing the internal thermal resistance inside the PCM container to achieve near uniform heat transfer by suitable measures such as the dispersion of nanoparticles in the PCM, adopting different geometrical arrangements for the PCM container is essential to operate the system successfully.

\section{Major challenges and future developments prospects}

The concept of thermal micro grid for cool energy application with the renewable power integration is not yet popularized, due to few challenges and further research requirements. The major challenges are (i) The integration of cool thermal storage system with the airconditioner/chiller units will reduce the capacity requirements of the cooling units, (ii) CTES technology is presently not promoted by the air-conditioning companies, as this will reduce their air-conditioning demand that will reduce their market potential, (iii) Normally customers will approach the air-conditioning companies for their building cooling requirement. Hence the awareness about the storage technology is not created among the customers. The future developmental prospects are: There is an increasing renewable energy scenario world-wide and hence there is an urgent requirement for energy storage. Among the various storage concepts cool thermal storage is an economically viable option. Further, when the end application is thermal energy and the system consumes electrical energy, the thermal storage will be the economically viable solution. Hence there is a high possibility of developments to overcome all the challenges associated with the technology in the near future.

$\begin{array}{ll}\text { Abbreviation } \\ \text { CNT } & \text { Carbon Nanotubes } \\ \text { CPVC } & \text { Chlorinated Polyvinyl Chloride } \\ \text { CTES } & \text { Cool Thermal Energy Storage } \\ \text { CUF } & \text { Capacity Utilization Factor } \\ \text { CWES } & \text { Cool Water Energy Storage } \\ \text { DI } & \text { Deionized } \\ \text { HDPE } & \text { High Density Polyethylene } \\ \text { HTF } & \text { Heat Transfer Fluid } \\ \text { INR } & \text { Indian Rupees } \\ \text { ITS } & \text { Ice Thermal Storage } \\ \text { LCA } & \text { Life Cycle Assessment } \\ \text { LCOE } & \text { Levelized Cost of Electricity } \\ \text { LPH } & \text { Liters per Hour } \\ \text { MWCNT } & \text { Multiwalled Carbon Nanotubes } \\ \text { NFPCM } & \text { Nanofluid Phase Change Material } \\ \text { PCM } & \text { Phase Change Material } \\ \text { PDTC } & \text { Proportionate Differential Temperature Controller } \\ \text { RTD } & \text { Resistance Temperature Detector } \\ \text { TES } & \text { Thermal Energy Storage } \\ \text { TR } & \text { Ton of Refrigeration } \\ \text { VCR } & \text { Vapor Compression Refrigeration } \\ & \end{array}$

\section{Acknowledgment}

The authors are highly thankful to the State Project Directorate, RUSA, Government of Tamilnadu, and RUSA, Ministry of Human Resource Development, Government of India, for the financial grant and support rendered.

\section{References}

Adhikari R.S, Aste N, Manfren M, Marini D,(2012) Energy savings through variable speed compressor heat pump systems, Energy Procedia, 14, 1337-1342: https://doi.org/10.1016/j.egypro.2011.12.1098

Aljehani A, Ali S, Razack K, Nitsche, L, Al-Hallaj, S. (2018) Design and optimization of a hybrid air-conditioning system with thermal energy storage using phase change composite. Energy Convers Manag 169, 404-18; https://doi.org/10.1016 lj.enconman.2018.05.040

Arcuri.B, Spataru.C,,Barrett.M. (2017).Evaluation of ice-thermal energy storage ( ITES ) for commercial buildings in cities in Brazil,.Sustain.Cities.Soc.,29,17192: https://doi.org/10.1016/j.scs.2016.12.011

Bédécarrats J.P., Lasvignottes J.C., Strub F., Dumas J.P., (2009). A Study of a phase change energy storage using spherical capsules. Part I: Experimental results. Energy Convers. Mgmt.50(10),2527-2536: https://doi.org/10.1016/j.enconman.2009.06.004

Boonnasa S, Namprakai P. (2010) The chilled water storage analysis for a university building cooling system. Appl. Therm. Eng 30(11-12), 1396-1408; https://doi.org/10.1016/j. applthermaleng.2010.02.029

Chandrasekaran P, Cheralathan M, Kumaresan V, (2014) Enhanced heat transfer characteristics of water-based copper oxide nanofluid PCM (phase change material) in a spherical capsule during solidification for energy-efficient cool thermal storage unit. Energy 72, 636-642; https://doi.org/10.1016/j.energy.2014.05.089

Chen S.L., Yue J. S., (1991). Thermal Performance of Cool Storage in Packed Capsules for Air Conditioning, Heat Recovery Syst CHP, 11(6), 551-561: https://doi.org/10.1016/08904332(91)90057-B

Cheralathan M, Velraj R, Renganarayanan S. (2007) Performance analysis on industrial refrigeration system integrated with encapsulated PCM-based cool thermal energy storage unit. Int $J$ Energy Res 1398-413; https://doi.org/10.1002/er.1313

Falco M De, Capocelli M, Losito G, (2017) LCA perspective to assess the environmental impact of a novel PCM- based cold storage unit for the civil air-conditioning. J Clean Prod 165, 697-704; https://doi.org/10.1016/j.jclepro.2017.07.153

Falco M De, Capocelli M, Giannattasio A. (2016) Performance analysis of an innovative PCM-based device for cold storage in the civil air-conditioning. Energy Build 122, 1-10; https://doi.org/10.1016/j.enbuild.2016.04.016

Kumaresan V, Chandrasekaran P, Nanda M, Maini, A.K, Velraj, R, (2013) Role of PCM based nanofluids for energy-efficient cool thermal storage unit. Int $J$ Refrig 36, 1641-1647; https://doi.org/10.1016/j.ijrefrig.2013.04.010

Lin H, Li X, Cheng P, Xu, B.G. (2013) A New Air-conditioning System with Chilled Water Storage. Applied Mechanics and Materials.296.48;

https://doi.org/10.4028/www.scientific.net/AMM.405408.2964

Lin H, Li X, Cheng P, (2014). Study on chilled energy storage of air-conditioning system with energy-saving. Energy Build. 79,41-46; https://doi.org/10.1016/j.enbuild.2014.04.047

Luo N, Hong T, Jia H, Li,R, Weng W, (2017). Data analytics and optimization of an ice-based energy storage system for 
commercial buildings, Appl. Energy, vol. 204, pp. 459-475: https://doi.org/10.1016/j.apenergy.2017.07.048

Mosaffa AH, Garousi FL, Infante FCA, (2014) Advanced exergy analysis of an air-conditioning system incorporating thermal energystorage. Energy, 77, 945-952: https://doi.org/10.1016/j.energy.2014.10.006

Patil V.R, Birada V.I, Shreyas R, Garg P, Orosz M.S, Thirumalai N.C. (2017), Techno-economic comparison of solar organic Rankine cycle (ORC) and photovoltaic (PV) systems with energy storage, Renew. Energy, 113,.1250-1260: https://doi.org/10.1016/j.renene.2017.06.107

Pina.E.A, Lozano.M.A, Serra.L.M. (2018), Allocation of economic costs in trigeneration systems at variable load conditions including renewable energy sources and thermal energy storage,Energy, 151,633-646: https://doi.org/10.1016/i.energy.2018.03.083

Rahdar MH, Emamzadeh A, Ataei A. (2016) A comparative study on PCM and ice thermal energy storage tank for airconditioning systems in office buildings. ApplThermEng 96, 391-96; https://doi.org/10.1016/j.applthermaleng.2015.11.107

Rivarolo M., Aristo Massardo, A.Greco (2013) Thermo-economic optimization of the impact of renewable generators on polygeneration smart-grids including hot thermal storage, Energy Convers.Manage.,65,pp-83,pp.

:http://dx.doi.org/10.1016/j.enconman.2012.09.005

Rosiek S, Garrido FJB. (2012) Performance evaluation of solarassisted air-conditioning system with chilled water storage (CIESOL building). Energy Convers. Manag 55, 81-92; https://doi.org/10.1016/j.enconman.2011.10.025
Sanaye S, Shirazi A. (2013) Thermo-economic optimization of an ice thermal energy storage unit for air-conditioning applications. Energy Build 60, 100-109; https://doi.org/ 10.1016/j.enbuild.2012.12.040

Sanaye S, Hekmatian M. (2016) Ice thermal energy storage (ITES) for air-conditioning application in full and partial load operatingmodes.IntJRefrig,66,181-197; https://doi.org/10.1016/j.ijrefrig.2015.10.014

Song X, Liu L, Zhu T, Chen, S, Cao, Z. (2018). Study of economic feasibility of a compound cool thermal storage unit combining chilled water storage and ice storage. Appl. Therm. Eng 133(25), $613-621$ ;https://doi.org/10.1016/j.applthermaleng.2018.01.063

Velraj R, Cheralathan M, Renganarayanan S. (2006) Energy Management through Encapsulated PCM Based Storage unit for Large Building Air-conditioning Application. IntEnergyJournal 7, 253-259;

Wang, Y., Liang, H., Dinavahi, V. (2019) Stochastic Demand Response under Random Renewable Power Generation in Smart Grid ) IEEE Power and Energy Society General, August, art.no. 8973824: https://doi.org/10.1109/PESGM40551.2019.8973824

Zhai XQ, Wang XL, Wang T, Wang, R.Z. (2013) A review on phase change cold storage in air-conditioning system: Materials and applications. Renew Sustain Energy Rev 22, 108-120; https://doi.org/10.1016/j.rser.2013.02.013

Zhu K, Li X, Campana P.E, Li H, Yan J,(2018). Techno-economic feasibility of integrating energy storage systems in refrigerated warehouses, Appl. Energy, 216, 348-357: https://doi.org/10.1016/j.apenergy.2018.01.079 